\title{
Práticas aplicadas no ensino de Genética para alunos da EJA (Educação de Jovens e
}

\section{Adultos)}

\author{
Practices applied in the teaching of Genetics to EJA students (Youth and Adult Education) \\ Prácticas aplicadas en la enseñanza de Genética a estudiantes de EJA (Educación de Jóvenes y \\ Adultos)
}

Recebido: 15/07/2021 | Revisado: 19/07/2021 | Aceito: 22/07/2021 | Publicado: 29/07/2021

\author{
Hilda Mara Melo Carvalho \\ ORCID: https://orcid.org/0000-0002-6754-7460 \\ Universidade Estadual do Piauí, Brasil \\ E-mail: maracarvalho1116@gmail.com \\ Francielle Alline Martins \\ ORCID: https://orcid.org/0000-0002-0113-8023 \\ Universidade Estadual do Piauí, Brasil \\ E-mail: franufv@yahoo.com.br \\ Pedro Marcos de Almeida \\ ORCID: https://orcid.org/0000-0001-5431-6818 \\ Universidade Estadual do Piauí, Brasil \\ E-mail: pedromarcosalmeida@yahoo.com.br \\ Josiane Silva Araújo \\ ORCID: https://orcid.org/0000-0002-2629-8306 \\ Universidade Estadual do Piauí, Brasil \\ E-mail: josianebio@hotmail.com
}

\begin{abstract}
Resumo
O ensino de biologia passou a ter novas estratégias que possibilitam ao professor aprimorar suas aulas, seus conhecimentos e transmiti-los de forma dinâmica, principalmente através de aulas práticas. O objetivo do presente estudo foi verificar a eficiência das aulas práticas como ferramentas na consolidação da aprendizagem em genética para alunos da Educação de Jovens e Adultos (EJA). O estudo foi desenvolvido em uma escola pública de TimonMA, em duas turmas de segunda etapa do EJA. Os resultados comprovam que a metodologia aplicada foi norteadora para o crescimento científico dos alunos da EJA.
\end{abstract}

Palavras-chave: Educação; Formação; Conhecimento; Dinâmica.

\begin{abstract}
Biology teaching now has new strategies that allow the teacher to improve his classes, his knowledge and transmit them in a dynamic way, mainly through practical classes. The objective of the present study was to verify if practical classes are effective tools for consolidating learning in genetics for students of Youth and Adult Education (EJA). The study was developed in a public school in Timon-MA, in two classes of second stage of the EJA. The results of this research proved that the applied methodology was guiding for the scientific growth of the students of the EJA.
\end{abstract}

Keywords: Education; Training; Knowledge; Dynamics.

\section{Resumen}

La enseñanza de la biología cuenta ahora con nuevas estrategias que permiten al docente mejorar sus clases, sus conocimientos y transmitirlos de forma dinámica, principalmente a través de clases prácticas. El objetivo del presente estudio fue verificar la eficiencia de las clases prácticas como herramientas en la consolidación del aprendizaje en genética para estudiantes de Educación de Jóvenes y Adultos (EJA). El estudio se desarrolló en una escuela pública de Timon-MA, en dos clases de segunda etapa de la EJA. Los resultados demuestran que la metodología aplicada estaba orientando el crecimiento científico de los estudiantes de EJA.

Palabras clave: Educación; Formación; Conocimiento; Dinámica.

\section{Introdução}

A EJA - educação de jovens e adultos - é uma modalidade de ensino destinado a jovens e adultos que não tiveram acesso ou que por algum motivo não puderam concluir o ensino na idade própria (referência).

Os educadores que se comprometem com a EJA preconizam a necessidade de buscar mecanismos, práticas e teorias 
que estimulem estes discentes a não abandonarem a sala de aula. Esses profissionais devem procurar métodos de ensino que estejam relacionados à realidade do público que estão trabalhando, inserindo no currículo a realidade do aluno, como destaca esse pensador: "Não há razão para se envergonhar por desconhecer algo, testemunhar a abertura dos outros, a disponibilidade curiosa à vida, a seus desafios, são saberes necessários à prática educativa" (Freire, 1979, p. 153).

O aluno da EJA possui diferenças na aquisição do conhecimento, principalmente por estar inserido no mundo do trabalho e das relações entre as pessoas de modo diferente da criança e do adolescente. Para Oliveira (1999, p. 119):

$\mathrm{O}$ adulto traz consigo uma história mais longa de experiências, conhecimentos acumulados e reflexões sobre o mundo externo, sobre si e sobre as outras pessoas. Com relação à inserção em situações de aprendizagem, essas peculiaridades da etapa da vida em que se encontra o adulto fazem com que ele traga consigo diferentes habilidades e dificuldades (em comparação com a criança) e, provavelmente, maior capacidade de reflexão sobre o conhecimento e seus próprios processos de aprendizagem.

A discussão sobre as metodologias ativas é crescente e buscam estimular as atividades de pensamento, que motivam o protagonismo estudantil, a capacidade de argumentação e questionamento, de pesquisa e reflexão. De forma que, havendo inúmeras alternativas não se justifica o emprego de apenas uma metodologia em sala de aula. Além disso, como o meio social fornece os dados para a pesquisa, o pesquisador se insere nessa realidade e por meio dos sentidos, aprende, tornando-se assim um elemento chave na coleta dos dados (Prodanov \& Freitas, 2013, p. 70).

Assim, a aula expositiva dialogada pode assumir o caráter de uma abordagem ativa da construção do conhecimento, pois deve instigar o questionamento do conhecimento apresentado, a reordenação dos conceitos apresentados numa clara mobilização do pensamento. Nesse sentido, Vickery (2016) afirma que:

O objetivo de todo ensino deve ser desenvolver uma abordagem de indagação independente à aprendizagem que munirá as crianças com duradouras habilidades da resiliência e do pensamento crítico. [...] O objetivo final deve ser criar alunos autônomos, ou seja, crianças com a mente aberta, capazes de pensar por si mesmas e relacionar esse pensamento com as suas experiências (Vickery, 2016, p. 51).

\subsection{Referencial Teórico}

Partindo do princípio de que tanto o docente como discente devem andar juntos e construir o conhecimento, o ensino, não só da biologia, mas de outras disciplinas. O professor deve dispor de recursos didáticos que auxiliem a relação teoria prática, pois a falta desses recursos pode colaborar para má formação de conceitos e incompreensão dos conteúdos. Para o Plano Plurianual de Alfabetização, da Secretaria de Educação do Estado da Bahia (2007, p. 06),:

[...] A prática educativa se revela na relação entre educador e educando como sujeitos do processo de ensinoaprendizagem, que juntos problematizam os conhecimentos oriundos da realidade social, construindo, assim, uma prática de educação. Nesta perspectiva, alfabetizar jovens e adultos é considerá-lo sujeitos do mundo e com o mundo, dando-lhes condições de ler e escrever a realidade global a partir do seu lugar social, transformando-os em autores da sua própria história e co-autores da história do seu país.

No entanto, observa-se que não somente as práticas pedagógicas, mas também se faz necessário o contato dos educandos com situações cotidianas abordativas de análises que possam levar os educandos a expor suas concepções e construírem concepções a partir dos dados obtidos através de experimentos realizados (Costa; Martins, 2016; Lima et al, 2020; Medeiros \& Goi, 2020).

Assim, além das práticas pedagógicas, é necessário o contato dos educandos com situações didáticas cotidianas que os levem a expor suas concepções e explicações a partir dos dados obtidos através das experiências realizadas (Costa; Martins, 2016; Lima et al,2020; Medeiros \& Goi, 2020). Nesse contexto, o ensino pode possuir um caráter investigativo, em que o 
mediador-professor apresenta questionamentos a serem indagados, instigue e oriente seus alunos no levantamento de hipóteses e na busca de explicações, por meio de práticas que façam associações com conceitos científicos, a fim de que construam conhecimento, sendo percebido como indivíduo investigativo, autônomo, crítico e reflexivo sobre suas respectivas ações (Carvalho, 2018; Lima; Pereira; Lima, 2021).

As sequências didáticas construídas a partir das indagações investigativas auxiliam o educando a produzir seu autoconhecimento. Desta forma, o aluno aprende pela observação, planejamento, reflexão, interpretação e construção de explicações próprias para determinada teoria. Para os autores, essa perspectiva é centrada no aluno, no desenvolvimento da sua autonomia, bem como na sua capacidade de tomar decisões e resolver problemas (Araújo; Bizzo, 2015; Carvalho, 2018).

Seguindo esta sistemática acima abordada, obtém-se a construção do conhecimento acercando-se de habilidades e competências para auxiliar a aprendizagem dos alunos e sua criatividade de desenvolver soluções a partir de fatos e experiências do cotidiano analisadas. Somente nesta ênfase, a abordagem investigativa possibilita ao educando solucionar problemas e estabelecer relações causais para explicar o fenômeno estudado (Sasseron, 2015). Carvalho (2018) expõe que o ensino investigativo se torna eficiente e importante quando existe essa problematização de forma clara e baseada no cotidiano dos alunos, pois dentro deste prisma eles poderão aplicar seu conhecimento prévio na busca por uma resolução, estabelecendo associações entre as informações que detêm e a construção de uma explicação.

Nesse contexto, é interessante que sejam utilizadas estratégias que possam facilitar a exposição de conceitos nas mais diversas áreas do conhecimento para os discentes da EJA. Com isso, umas das formas de melhorar a relação ensinoaprendizagem em biologia é com aplicação de atividades práticas. Na genética, a necessidade de técnicas que auxiliem na demonstração do conteúdo é de suma importância pela complexidade e abstração destes. Então, o presente trabalho teve como objetivo propor aulas práticas como ferramentas na consolidação da aprendizagem em genética para alunos da EJA.

\section{Metodologia}

\section{Categorização da pesquisa}

O Termo de Consentimento Livre e Esclarecido (TCLE) e coleta de dados foram executados após aprovação do Comitê de Ética e Pesquisa (CEP) da Universidade Estadual do Piauí (UESPI), sob o protocolo 3.496.202, respeitando a Resolução 466/12 do CNS/MS.

\section{Amostra}

$\mathrm{Na}$ realização desta pesquisa foi utilizada a abordagem qualitativa-quantitativa, tratando-se de uma pesquisa diagnóstica de acordo com as análises de Bardin (2011), como forma de comparar a eficácia das estratégias utilizadas (aulas expositivas, práticas e questionários) na aprendizagem dos alunos da EJA na disciplina Genética. A pesquisa foi realizada com estudantes da segunda etapa da EJA, do Ensino Médio de uma escola pública, localizada no município de Timon (Maranhão).

\section{Procedimentos}

O universo amostral selecionado foi composto por 71 discentes de três turmas (noturno) divididos em 27 homens e 44 mulheres, todos cursando a segunda etapa da EJA, momento em que o conteúdo de Genética é ministrado. Todos os participantes possuem idade entre 20 e 44 anos.

Primeiramente, foi realizada uma abordagem dialogada dos conteúdos de forma teórica com esquemas no quadro, seguindo o planejamento anual dos conteúdos de Genética ministrados para o ensino médio e selecionados para a modalidade EJA, partindo da análise do DNA, estrutura dos cromossomos e montagem do cariótipo, Leis de Mendel e sistema ABO.

Em seguida, foi realizada a aplicação de um questionário avaliativo antes dos conteúdos ministrados, depois ocorreu 
uma abordagem dos conteúdos de forma teórica e com esquemas no quadro. Após a realização das práticas dos conteúdos mencionados, foi observado o nível de aprendizado dos discentes e associado as aulas expositivas, foi aplicado outro questionário avaliativo. Estes questionários possuíam 5 questões objetivas (1,0 ponto/questão) para cada conteúdo e foi considerado aprovado o rendimento de mais de três acertos em ambos os questionários a fim de atingir a média de 6,0 pontos aprovativa na escola. É importante ressaltar que as questões dos dois questionários (um antes e outro depois das aulas práticas) tiveram o mesmo grau de dificuldade para que fosse possível verificar o nível de conhecimento referente aos temas básicos de Genética desenvolvidos no ensino médio e selecionados para esta modalidade.

Em um primeiro momento, foi realizada a aula prática do "DNA Comestível". O objetivo dessa proposta foi que o aluno pudesse conhecer a estrutura da molécula de DNA evidenciando as bases nitrogenadas (AT e CG), as ligações de hidrogênio entre as bases e o modelo da dupla-hélice do DNA. Os alunos se reuniram em grupos, montaram uma molécula de DNA usando jujubas de diferentes cores (quatro cores), cada cor representou uma das bases nitrogenadas (A, T, G e C), encaixadas em dois fios de arame, aleatoriamente e no outro o encaixe obedeceu à combinação entre as bases (AT/TA/CG/GC). Um fio foi unido ao outro, através das jujubas, por palitos de dentes que representaram as ligações de hidrogênio e os fosfatos por massa de goma comestível. Ao concluírem a montagem da molécula de DNA, os alunos fizeram um giro helicoidal na molécula comestível, obedecendo ao modelo proposto por Watson e Crick. Esta proposta lúdica foi desenvolvida por Lima et al (2005).

A segunda prática foi a "Extração do DNA Humano" em células da mucosa bucal. Os estudantes foram divididos em grupos, logo em seguida extraíram o DNA humano utilizando produtos (reagentes) caseiros como detergente, sal, álcool, água e gelo. À medida que tais reagentes foram utilizados, os discentes compararam aos reagentes usados em extrações de DNA científicas de acordo com a função desempenhada por cada um deles. Ao término da extração, os alunos visualizaram o DNA com o aspecto de um "chumaço de algodão" e receberam orientações sobre a finalidade de se extrair o material genético dos seres vivos; assim como também de enfatizar a importância do DNA para as informações genéticas, de acordo com o site https://blog.mesalva.com/curiosidades-cientificas/experimento-extracao-de-dna-caseira/.

A terceira prática foi a "Montagem de Cariótipos", com o objetivo de observar a estrutura dos cromossomos humanos e dos macacos, fazer as comparações e observar as semelhanças e diferenças entre eles. Os alunos foram organizados em grupos e logo a seguir fizeram colagens e analisaram as possíveis alterações cromossômicas que diferenciaram essas espécies ao longo do tempo. Após a montagem, os alunos receberam algumas perguntas discursivas para comprovar as mudanças ocorridas e entender o que tornou macacos e humanos parentes na linha evolutiva (aula fornecida pela UFMG do Mestrado PROFBIO). Foi de extrema importância a descoberta que o parente mais próximo do homem é o chimpanzé e as dificuldades foram entender o processo de mutação do tipo reversão e posterior fusão dos pedaços, assim como também associar o processo de comparação dos pedaços paralelos do cariótipo do homem e dos macacos.

A quarta prática foram às "Leis de Mendel Aplicadas aos Caracteres Humanos", que teve como objetivo esclarecer a compreensão da formação das características hereditárias através da junção de alelos (Amabis, 2001). Nesta atividade, os alunos com o auxílio de uma moeda montaram de forma aleatória fenótipos do rosto humano em uma folha que possuía o formato de rosto humano. Cada característica foi determinada por uma dupla (um representando o pai e outro a mãe), onde cada um, ao jogar o dado, forneceu um alelo para a característica escolhida. Com a união dos alelos, foi possível determinar o fenótipo em questão, o qual foi montado no formato de um rosto humano.

A quinta prática foi uma proposta alternativa para o ensino dos grupos sanguíneos $\mathrm{ABO}$. Os alunos se organizaram em grupos e prepararam um modelo didático, de baixo custo e fácil confecção, que concretiza e complementa o ensino teórico sobre os fundamentos bioquímicos relacionados ao sistema ABO. Para esta atividade, foram utilizados copos descartáveis transparentes, água, suco em pó de uva e laranja e colher de plástico. Os alunos realizaram misturas de cada tipo sanguíneo 
conforme as cores dos sucos e responderam perguntas feitas pelo professor sobre transfusões e características dos tipos sanguíneos. Durante as perguntas misturaram seus ingredientes para confirmarem as respostas, segundo o site pontobiologia.com.br

\section{Análise dos resultados}

A análise de dados foi baseada na quantidade de acertos e erros em gráficos e tabelas, a fim de avaliar o grau de aprendizagem dos conteúdos assimilados pelos discentes.

\section{Resultados e Discussão}

A pesquisa possibilitou um estudo sobre a importância das aulas práticas na EJA para nortear o ensino de Genética. Após a realização das práticas, foram analisadas a quantidade de acertos e erros dos alunos nos questionários avaliativos aplicados em sala antes e depois e a progressão da aprendizagem dos discentes em relação aos conteúdos ministrados.

O questionário avaliativo aplicado antes da aula prática mostrou que vinte alunos tiveram quatro acertos e um erro, dezenove apresentaram dois acertos e três erros e trinta e dois com três acertos e dois erros. Após a realização da prática, observou-se que sessenta e nove alunos obtiveram cinco acertos e três alunos obtiveram quatro acertos e um erro, retratando uma melhora do desempenho dos discentes após a utilização de uma atividade diferenciada, conforma nos mostra a Figura 1.

Figura 1: Proporção absoluta da relação quantidade de alunos/questionário avaliativo aplicado antes e depois da aula prática do DNA comestível aos alunos da EJA em uma escola estadual de Timon- MA.

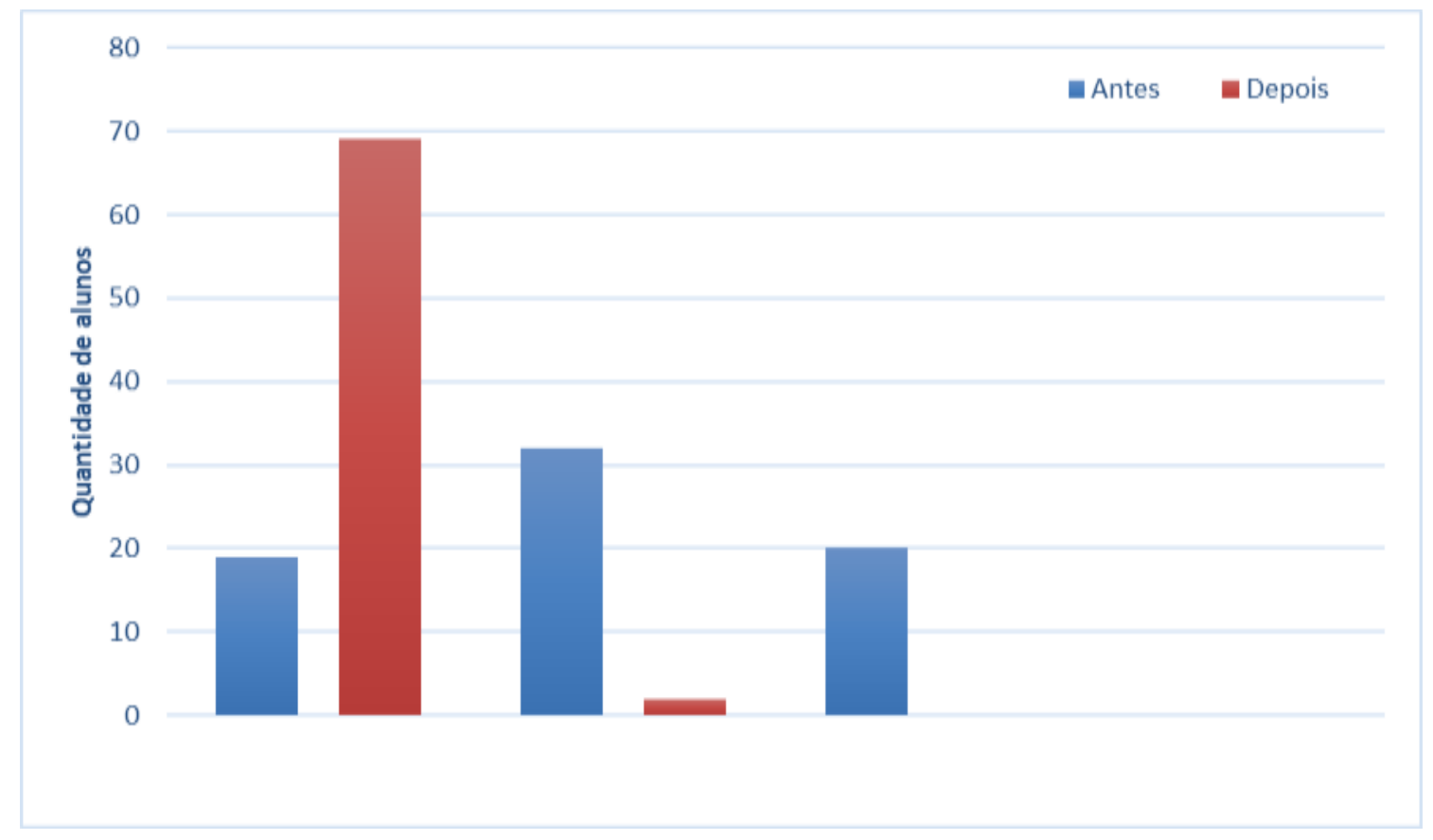

Fonte: Compilação das autoras (2021).

As investigações em Ensino de Ciências têm revelado a importância das concepções dos alunos no processo de ensino/aprendizagem. Existem evidências que durante esse processo, um conceito já existente, ainda que falso em um plano científico, serve de sistema explicativo eficaz e funcional para o estudante (Astolfi \& Develay, 1990, citado por Rebello, 2000). 
O questionário avaliativo antes da segunda aula prática (Figura 2) mostrou que cinquenta alunos tiveram três acertos e dois erros e vinte e um apresentaram quatro acertos e um erro. Após a prática, observou-se quarenta e quatro alunos com quatro acertos e um erro e vinte e sete com cinco acertos, mostrando a melhora do desempenho dos discentes. Foi observado nas duas primeiras práticas de DNA que os estudantes não tiveram dificuldades de associar a teoria com a prática, pois além de já terem visto esse assunto na etapa anterior, os discentes tiveram uma aula dialogada antes para relembrar. Assim, a dificuldade encontrada inicialmente foi associar as jujubas em cores de acordo com as bases nitrogenadas estudadas do DNA, já que cada grupo determinou as suas cores antecipadamente para a construção da molécula do DNA comestível.

Foi observado, nas duas primeiras práticas de DNA, que os estudantes tiveram poucas dificuldades de associar a teoria com a prática, pois, além de já terem visto esse assunto na etapa anterior, os discentes tiveram uma aula dialogada antes para relembrar.

Figura 2: Proporção absoluta da relação quantidade de alunos/questionário avaliativo aplicado antes e depois da aula prática da Extração de DNA em humanos aos alunos da EJA em uma escola estadual de Timon- MA.

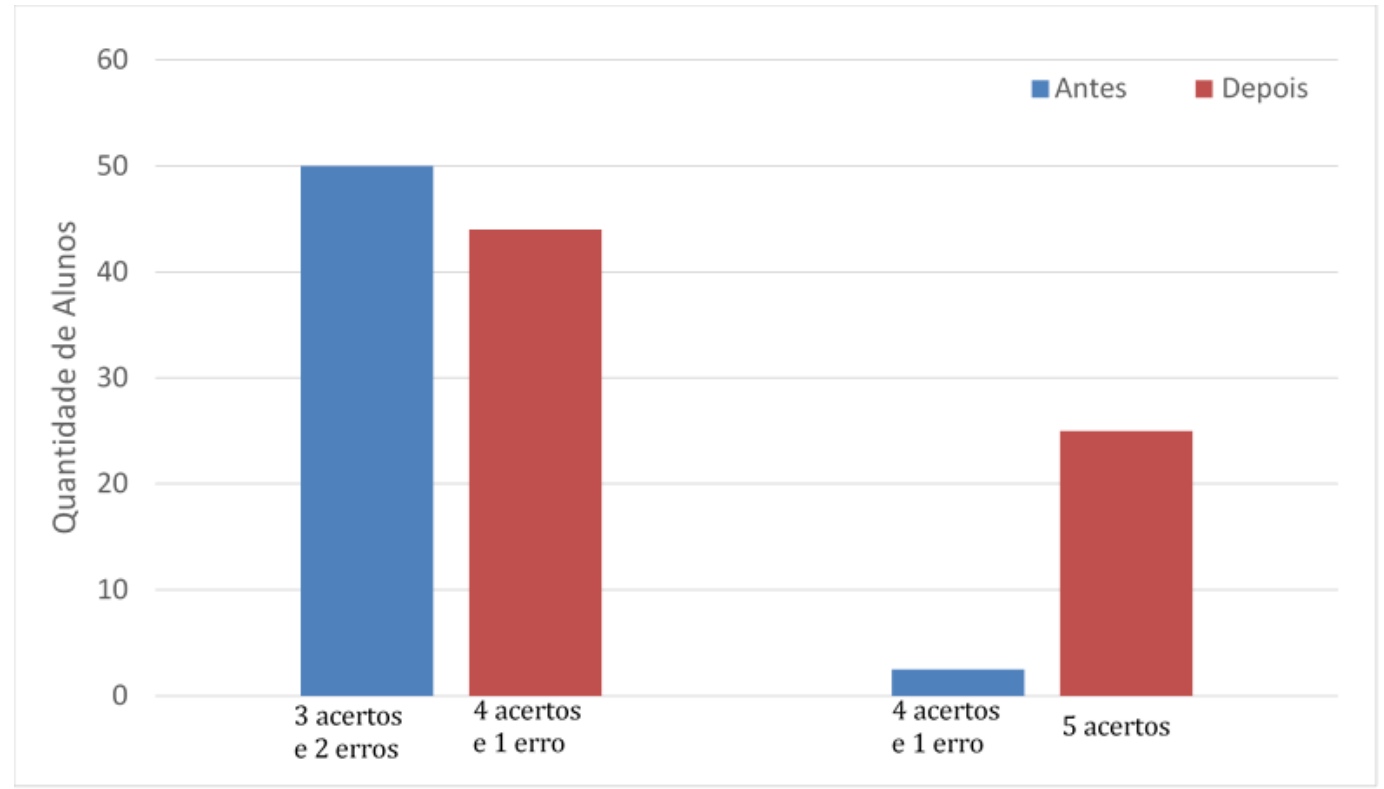

Fonte: Compilação das autoras (2021).

Na segunda prática, a maior dificuldade encontrada foi associar a função do sal, do detergente e do álcool em relação a célula da mucosa oral, pois estudaram membrana na etapa anterior e ainda sentiam dificuldades de entender à disposição e polarização da membrana em relação a disposição dos lipídeos.

Foi bastante interessante porque o discente participou da prática com a utilização de suas células bucais e aproximou o aluno do objeto, pois ficou bem claro que todas as nossas células possuem DNA e que este pode ser separado através de matérias de baixo custo e caseiro.

Alguns autores, como Rocha (2013) e Soares e Baiotto (2015) tratam em seus trabalhos sobre a importância das aulas práticas para o processo de ensino-aprendizagem em Genética. Eles discutem que esse tipo de metodologia facilita a assimilação dos conteúdos, além de permitir uma maior interação entre os estudantes e os assuntos abordados na disciplina de Biologia.

O questionário avaliativo antes da terceira aula prática (Figura 3) mostrou que quarenta e dois alunos com três acertos e dois erros, vinte e um alunos com quatro acertos e um erro, seis alunos com cinco acertos, dois alunos com dois acertos e três 
erros. Após a prática, observou-se que quarenta e nove alunos tiveram quatro acertos e apenas um erro; vinte acertaram cinco questões e apenas dois erraram um número maior de questões (três) e acertaram apenas duas questões, retratando uma melhora do desempenho dos discentes.

Figura 3: Proporção absoluta da relação quantidade de alunos/questionário avaliativo aplicado antes e depois da aula prática de Montagem de cariótipos de humanos e macacos aos alunos da EJA em uma escola estadual de Timon- MA.

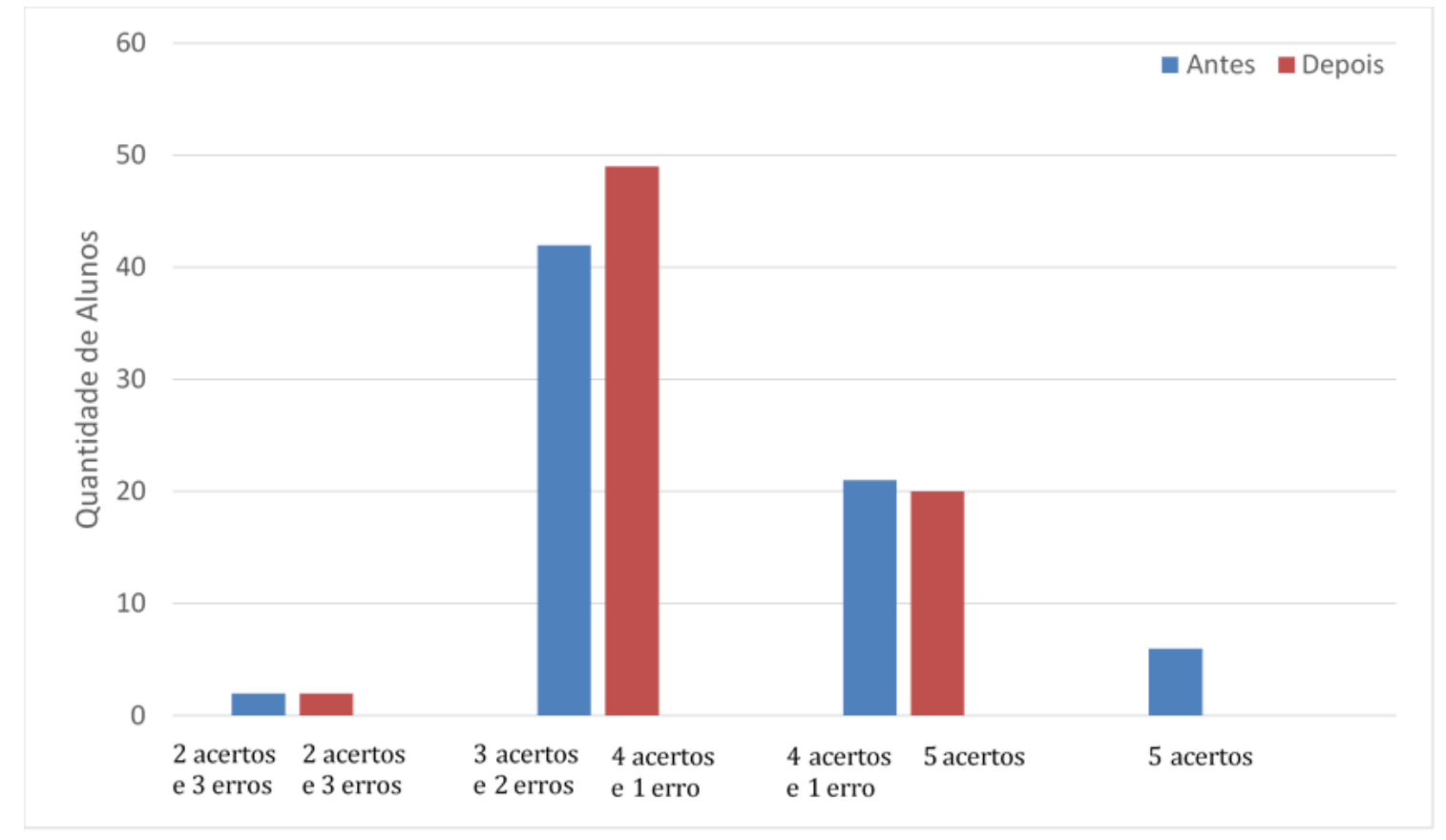

Fonte: Compilação das autoras (2021).

Os alunos sentiram dificuldades para comparar o cariótipo do homem com os macacos e entender a rotação de $180^{\circ} \mathrm{e}$ fusão deles, precisaram e auxílio constante do professor durante o processo. Assim como também não ficaram convencidos do parentesco destes animais.

Mas alguns discentes não ficaram convencidos do parentesco destes animais e muitos não acreditaram nesta linha evolutiva do ancestral em comum entre essas espécies por motivos religiosos, porém foi indicada a proximidade destas espécies através da ciência para se concretizar a prática.

Lima e Vasconcelos (2006) informam que um desafio imposto pelo professor é aplicar práticas pedagógicas acompanhadas de práticas conceituais. As práticas auxiliam os alunos a relacionar os conceitos à sua realidade, dando significado e importância ao assunto de Genética que vem sendo abordado em sala. Dessa forma, abordagens metodológicas inovadoras, que envolvam arte, modelos, jogos e práticas inovadoras mostram-se promissores para melhorar a qualidade do ensino e facilitar a transmissão dos conteúdos, permitindo assim a apropriação do aluno do novo tema abordado.

$\mathrm{Na}$ quarta atividade prática, o questionário avaliativo antes da aula (Figura 4) mostrou que cinquenta alunos acertaram três questões e erraram duas, enquanto três acertaram apenas uma e dezoito tiveram dois acertos e um erro. Após a prática (Figura 4), cinquenta e quatro alunos tiveram três acertos e dois erros e dezessete acertaram as cinco questões, melhorando o desempenho dos discentes. 
Figura 4: Proporção absoluta da relação quantidade de alunos/questionário avaliativo aplicado antes e depois da aula prática de Leis de Mendel aplicada aos caracteres humanos aos alunos da EJA em uma escola estadual de Timon-MA.

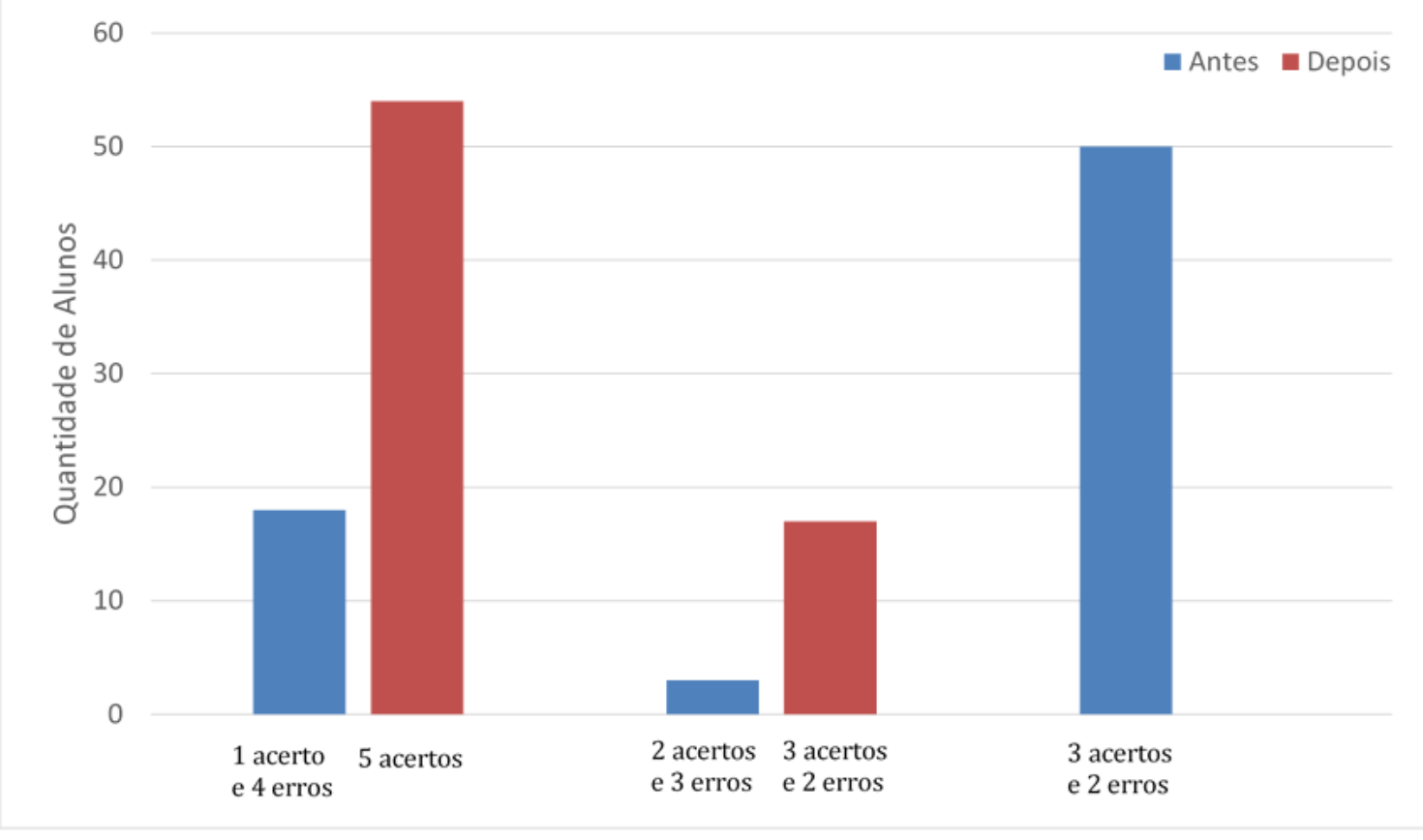

Fonte: Compilação das autoras (2021).

Os alunos sentiram dificuldades de associar o processo de probabilidade eventual com as características predeterminadas fornecidas anteriormente através do lançamento da moeda, mas logo se adaptaram e construíram os rostos humanos das mais diferentes formas.

Assim, as aulas práticas, se aliadas à teoria, podem constituir uma poderosa ferramenta, aumentando o interesse do aluno em relação aos conteúdos de Biologia. Porém, é necessário que os conteúdos apresentados na teoria sejam feitos de forma clara, visando o bom entendimento do aluno.

Neste sentido, Andrade e Massabni (2011) asseguram que a atividade prática é uma tarefa desenvolvida manualmente, seja feita pelo professor, na qual os alunos analisam, ou que os próprios alunos façam, desde que haja a presença do objeto materialmente, ou seja, os alunos aprendem experimentando, como afirma Piaget, posto que as experimentações geram um grande instrumento de aprendizagem.

O questionário avaliativo antes da quinta aula prática (Figura 5) mostrou que 60 alunos fizeram quatro acertos e um erro e onze tiveram cinco acertos. Após a prática, observou-se que setenta e um alunos fizeram cinco acertos, retratando uma melhora do desempenho dos discentes.

Foi uma aula muito divertida, pois os discentes criaram rostos diferentes e observaram que as características hereditárias vêm do pai e da mãe, na mesma proporção e podem formar filhos bem diferentes devido as recombinações genéticas. 
Figura 5: Proporção absoluta da relação quantidade de alunos/ número de acertos e erros do questionário avaliativo aplicado antes e depois da aula prática de sistema sanguíneo ABO aos alunos da EJA em uma escola estadual de Timon-MA.

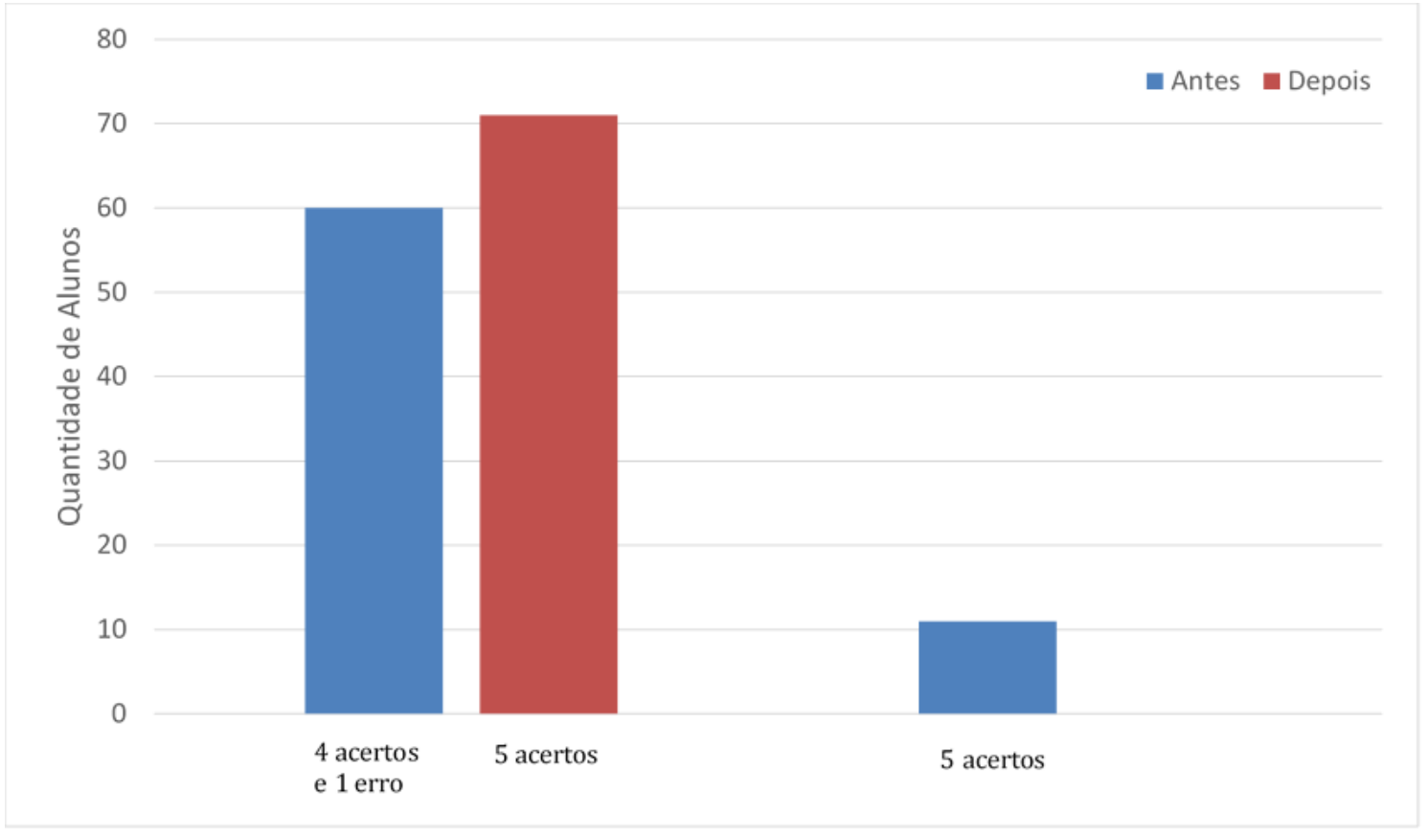

Fonte: Compilação das autoras (2021).

Os alunos não apresentaram dificuldades, nem durante a aula prática tampouco durante a realização dos questionários, chegando assim à afirmação que a temática dos tipos sanguíneos foi de suma importância para cotidiano dos discentes, sendo totalmente assimilada.

Foi uma prática onde eles se deslocavam aos demais grupos e misturaram os componentes de seus copos com os dos colegas, observando onde poderia ter transfusões sem incompatibilidade sanguínea; assim como também ficou bem claro a presença de aglutinogênios em cada tipo sanguíneo.

De acordo com Marandino (2003), a prática de ensino se dá exatamente na junção entre os saberes pedagógicos e científicos, fato que pode ser confirmado com o presente estudo, no qual os discentes puderam associar teoria à prática com a utilização de atividades relativamente simples, mas que puderam melhorar o entendimento dos conteúdos abordados.

\section{Considerações Finais}

Percebe-se que, ao se trabalhar alguns assuntos de Genética associados a essas aulas práticas, os alunos puderam associar os conhecimentos adquiridos ao seu cotidiano e deslumbrar as formas e estruturas de moléculas como o DNA, comparação de cariótipos de humanos e macacos, as Leis de Mendel e o sistema ABO que os aproximaram dos conteúdos desta disciplina e contribuiu para a formação crítica de cidadão.

De acordo com a pesquisa realizada, ficou caracterizada que as diferentes formas abordadas por professores em sala, através das práticas pedagógicas, se fazem necessárias para promover o desenvolvimento criativo e investigativo dos educandos, trazendo benefícios para a posterior construção do conhecimento e permitindo o desenvolvimento da atuação deste com a ciência.

Acredita-se que estudos relacionados a comparação da inserção de metodologias ativas no contexto de discentes em diferentes níveis de ensino pode ter resultados interessantes e são pesquisas que devem ser realizadas para que se tenha um melhor entendimento sobre como os estudantes reagem diante desse tipo metodologia. 
Research, Society and Development, v. 10, n. 9, e43510918286, 2021

(CC BY 4.0) | ISSN 2525-3409 | DOI: http://dx.doi.org/10.33448/rsd-v10i9.18286

\section{Referências}

Amabis, J. M. \& Martho, G. R. (2001). Guia de apoio didático. Moderna.

Andrade, M. L. F. \& Massabni, V. G. (2011). O desenvolvimento de atividades práticas na escola: um desafio para os professores de ciências. Ciência \& Educação, 17(4), 835-854.

Araújo, M. I. O., \& Bizzo, N. (2015) Processo investigativo sobre práticas pedagógicas para inserção da dimensão ambiental na formação de professores de Biologia. Revista Tempos e Espaços em Educação, 8(16), 125-138.

Astolfi, J. P. \& Develay, M. A. (1990). A didática das ciências. Papirus.

Bahia. Plano Plurianual de Alfabetização (2007). Secretaria de Educação do Estado da Bahia.

Bardin, L. (2011). Análise de conteúdo. Edições 70.

Carvalho, A. M. P. (2018). Fundamentos teóricos e metodológicos do ensino por investigação. Revista Brasileira de Pesquisa em Educação em Ciências, 18(3), 765-794.

Costa, C., \& Martins, I. P. (2016) Educação em ciências no primeiro ciclo do ensino básico para desenvolvimento sustentável. Indagatio Didactica, 8(1), 3045 .

Freire, P. (1979). Conscientização teoria e prática de libertação. Cortez e Morais.

Lima, G. H. et al. (2016). O uso de atividades práticas no ensino de ciências em escolas públicas do município de Vitória de Santo Antão - PE. Rev. Ciênc. Ext., 12(1), 19-27.

Lima, K. E. C. \& Vasconcelos, S. D. (2006). Análise da metodologia de ensino de ciências nas escolas da rede municipal de Recife. Ensaio: Revista avaliação de políticas públicas educacionais, 14(52), 397-412.

Lima, M. M. O., Cardoso, T. C., Santos Filho, F. S., Martins, F. A., \& Almeida, P. M. (2020) Atividades práticas de Biologia: uma Sequência de Ensino Investigativa sobre o Ciclo Celular. Research, Society and Development, 9(9), e611997801.

Marandino, M. A prática de ensino nas licenciaturas e a pesquisa em ensino de ciências: questões atuais. (2003). Caderno Brasileiro de Ensino de Física, 20(2), 168-193.

Marques, W. O quantitativo e o qualitativo na pesquisa educacional. (1997). Avaliação: Revista da Avaliação da Educação Superior, 5(3), $19-31$.

Medeiros, D. R., \& Goi, M. E. J. (2020). A Resolução de Problemas como uma metodologia investigativa no Ensino de Ciências da Natureza. Research, Society and Development, 9 (1), 1-32.

Oliveira, A. A (1999). Experiência Educativa Popular Freireana do Pro Alto. In A. M. A. Freire, Ana Maria Araújo (Ed.). A pedagogia da libertação em Paulo Freire. UNESP.

Prodanov, C. C. \& Freitas, E. C. (2013). Metodologia do trabalho científico. FEEVALE.

Rocha, L. S. (2013). Estratégias metodológicas para ensinar genética no Ensino médio. [Monografia da Especialização em Educação: Métodos e Técnicas de Ensino, Universidade Tecnológica Federal do Paraná].

Sasseron, L. H. (2015) Alfabetização científica, ensino por investigação e argumentação: relações entre ciências da natureza e escola. Revista Ensaio, 17(1), 49-67.

Soares, R. M. \& Baiotto, C. R. (2015). Aulas práticas de biologia: suas aplicações e o contraponto desta prática. Revista Di@logus, 4(2), 53-68.

Tudo sobre Biologia. (n.d). PontoBiologia.com. www.pontobiologia.com.br

Vickery, A. (2016). Aprendizagem ativa. Penso. 